\title{
Youth in Bangladesh: Demographic Dividend or Demographic Disaster
}

\author{
Amima Najnin Maria* \\ Lecturer, Department of Economics \\ Faculty of Arts and Social Sciences, Hamdard University Bangladesh \\ Hamdard City of Science, Education \& Culture Gazaria, Munshiganj \\ *email: amima_565@yahoo.com
}

\begin{abstract}
This study explores vital insights into the challenges facing youth in terms of employment opportunities in Bangladesh. Youth employment challenges are apparently to be related with the demographic challenges posed by growing youth populations in upcoming decades. Bangladesh since 2007 has had more working aged population than non-working, known as demographic dividend, and by 2040 this casement would begin to close. However, not being able to provide right match of employment opportunities for this lot of young people as they penetrate the labour market risks a 'demographic disaster'. Bangladesh will need educated, healthy and productive labour force to en-cash its demographic dividends. This paper addresses the nature of employment profile of youth in Bangladesh with focus on the suggestions for challenges. The research methodology used is qualitative with major focus on secondary data.
\end{abstract}

Keywords: Youth, Employment, Demographic Dividend, Demographic Disaster, Bangladesh

\section{Introduction}

The youth population in any country is dynamic and vital for its long run development. If the benefits of demographic dividend are attained, per capita income will rise and with more people economically active, the savings rate will also increase.

Investing in young people is critical for seizing the demographic dividend. South Korea, Singapore, Taiwan, and Thailand experienced spectacular economic growth during the second half of the 20th century, much of which was due to the demographic dividend. The economy of Bangladesh has been showing improvement. Therefore, Bangladesh can take full advantage of the demographic dividend. However, many developing countries, including Bangladesh will not be able to achieve this economic benefit without appropriate policies and substantial investments in some areas (Arefin, 2018). According to analysts, currently Bangladesh is passing through the phase of demographic dividend that emerged in 2007. At present, we are at the midway point of the dividend period. So a good question to ask is, how has this demographic dividend transformed Bangladesh today and how will it transform Bangladesh tomorrow?

Bangladesh is considered one of the fastest growing economies in the world. For the last decade and a half, the country recorded the highest ever growth at 7.86 percent. Our per-capita income is USD 1,751 which was only USD 405 in the year 2000. Spectacular progress in different socio-economic sectors, particularly relating to reducing extreme poverty and hunger, promoting gender equality and empowering women, ensuring universal primary education and reducing child mortality has been made. Life expectancy went up to 72.3 years in 2019 from 65.32 years in 2000 .

While Bangladesh has a long list of achievements to our credit, it has failed on many fronts. It still remains one of the poorest, overpopulated and inefficiently governed countries in the world. The country is still struggling with a huge pool of low-skilled workforce; about 86 percent of the total employed population aged 15 and above are in the informal sector, which is insecure, poorly paid and has no social security, which means that they cannot contribute much to economic development. Almost one in four Bangladeshis (24.3 percent of the population) lives in poverty, 12.9 percent of the population live in extreme poverty, 15.2 percent of the country's population suffer from undernourishment, while 36.1 percent of children under the age of five face growth development issues.

Moreover, the rapid economic growth has also failed to create enough jobs for the millions of young Bangladeshis joining the workforce every year which is termed as 'Jobless growth'. The overall employment elasticity with respect to GDP growth declined from 0.54 during 1995-2000 to 0.25 in 2010-2018. What is worrying is that the share of the youth population not in education, economic activities and training (NEET) increased from 25.4 
percent in 2013 to 29.8 percent in 2016-17-more than one-fourth of all young people are not participating in any form of economic or educational activities (Haider, 2019).

However it is vital to grasp that there will not be any dividend without investment, in either cash or kind. So time has come to think -What Bangladesh has invested in youth?

The broad objective of the research paper is to answer an important question - Whether the youth in Bangladesh will lead to be a demographic dividend or demographic disaster?

The broad objective is investigated through the following sub-objectives:

i. To examine the nature of the youth employment

ii. To suggest recommendations for challenges with respect to youth unemployment in Bangladesh.

\section{Background of the study}

\subsection{Global Scenario with respect to Employment}

New global data collected by the ILO for 2018 point to some progress, but above all reveal the persistence of significant decent work deficits, with the various regions facing challenges of many different kinds.

\subsection{The Global Labour Market at a Glance}

In 2018, the global working age-population, comprising women and men aged 15 years or older, was 5.7 billion. Out of these, 3.3 billion people, or 58.4 per cent, were in employment, and 172 million were unemployed. Both these groups taken together constitute the global labour force, which therefore stood at 3.5 billion in 2018 , implying a labour force participation rate of 61.4 per cent. The remaining 2.2 billion people (38.6 per cent) of working age were outside the labour force, including those engaged in education and unpaid care work and those in retirement. Within this group, 140 million were in the potential labour force (i.e. people who are looking for a job but are not yet available to take up employment, or who are available but are not looking for a job).

Statistics on employment and labour force participation reflect the definitions established in the relevant resolutions of the International Conference of Labour Statisticians (ICLS), which are updated periodically to adjust to the changing world of work. For instance, the 19th ICLS, held in 2013, narrowed the definition of employment to refer only to activities performed for others in exchange for pay or profit. At the same time, the definition of work was expanded to include also the production of services for own use, such as unpaid care work (ILO, 2013). Neither these changes nor those introduced in the most recent relevant resolution, which was adopted by the 20th ICLS (ILO, 2018), are reflected in the global labour market statistics presented in this report. New questionnaires for labour force surveys are still being designed and tested with the support of the ILO. For the time being, globally consistent data based on the new definitions are not yet available for a number of countries that is sufficiently large to yield reliable aggregates.

\subsection{Declining Employment, Labour Force Participation and Gender Gap}

The average annual growth of the global working-age population has decreased from 1.9 percent in the period 1990-95 to 1.3 per cent in the period 2013-18; it is projected to fall even further, to 1.1 percent, by 2030 . Around 61 per cent of the world's working-age population participates in the labour market either by being actually employed or by searching for employment while being available for work. This participation rate has been declining on average by between 0.1 and 0.2 percentage points per year over the past 25 years, with the steepest drop occurring in the aftermath of the global financial crisis of 2008. Aggregate participation rates vary across country income groups, ranging, in 2018, from 56 percent in lower-middle-income countries to 71 per cent in low-income countries. Participation rates are expected to decline in all country income groups between 2018 and 2023, most markedly in upper-middle-income countries (by 2 percentage points) and high-income countries (by 1 percentage point).

The much lower labour force participation rate of women, which stood at 48 per cent in 2018, compared with 75 per cent for men, means that around three in five of the 3.5 billion people in the global labour force in 2018 were men. Overall, labour force participation rates among adults have been declining for the past 25 years; the decline is even more pronounced among young people aged 15-24. This downward trend is projected to continue in the future (ILO, 2019). 


\subsection{Global Scenario with respect to Youth Employment}

Globally, the ILO predicts that the amount of jobless youth is on the increase since 2011 and after declining somewhat from the peak it reached at the height of the worldwide monetary crisis.

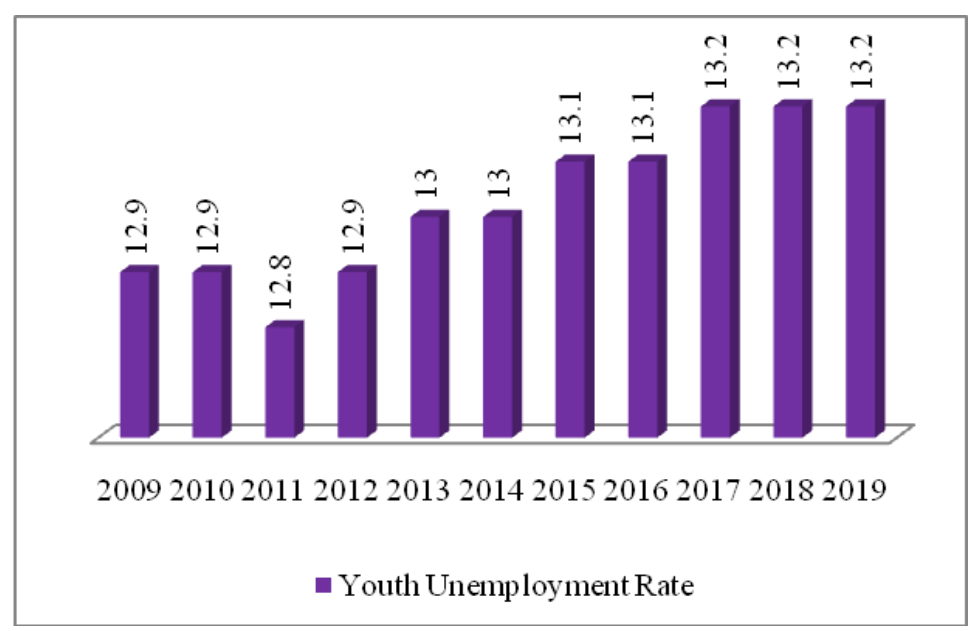

Figure 1. Global Youth Unemployment Rate (\%) ((2009- 2019)

Source: Statista 2019

The statistic shows the global youth unemployment rate from 2009 to 2014 with a forecast up to 2019 . The global youth unemployment rate was at 12.9 percent in 2012 and it is projected to rise to 13.2 percent by 2019 (Figure 1). According to the report of ILO, more than 1 in 5 young persons are not in employment, education or training (NEET) and 3 out of 4 of these are women. In addition, more than 64 million unemployed youth worldwide and 145 million young workers living in poverty and thus youth employment still remains a global challenge and a top policy concern (ILO, 2019).

Bangladesh population is equivalent to $2.18 \%$ of the total world population. The Census of Bangladesh (2011) has sketched the profile and status of the adolescent and youth population, which comprises a vital segment of the total population of Bangladesh since socio-political, economic and demographic developments rely on them. The transition from education and training to economic activity marks a crucial phase in the lives of youth, who are the operative workforce of the country. The high level of unemployment among youth is mainly due to lack of skills, low level of education, lack of employment opportunities and poverty which in turn, is a long term challenge for Bangladesh (Naik \& Bobade, 2016).

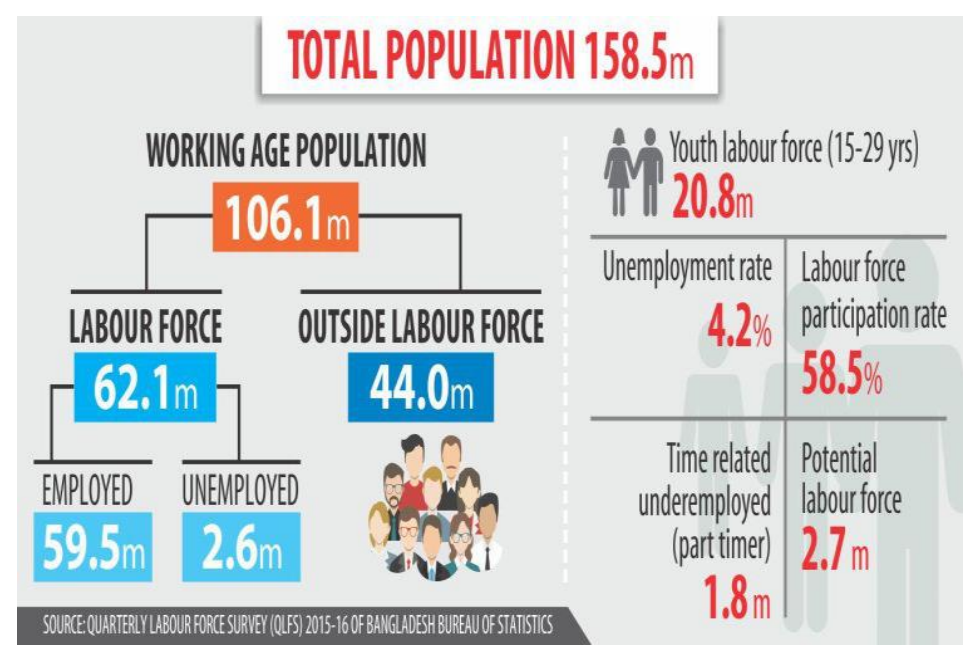

Figure 2: Labour Market Scenario of Bangladesh

Source: Quarterly Labour Force Survey of BBS 
Now in Bangladesh total population is $\mathbf{1 5 8 . 5}$ million. Working age population is 106.1 million. Actual Labour force is 62.1 million (59.5 million employed in public and private sectors, 2.6 million is still unemployed) and outside labour force people gossiping in tea stalls are 44.0 million. Youth labour force (15- 29 years) is 20.8 million. The rate of unemployment is 4.2 per cent and the labour force participation rate is 58.5 per cent. In agriculture sector disguised underemployment is season-based and employment is 1.8 million (Figure 2). Outside Bangladesh, it is 108 million (Quarterly Labor force Supply Report 2015-2016 of Bangladesh Bureau of Statistics). The jobs still are inadequate for 106 million working-age population in Bangladesh (Arefin, 2018).

Youth is defined as those persons in the age group 15-24 years by the United Nations, while following Bangladesh Bureau of Statistics (BBS), the age group of 15-29 years is considered as the age groups of youth. During this transitional phase, physical, educational, psychological, social and economic changes occur in their lives. Youth is a more dynamic segment than a fixed age-group. Youth is commonly indicated as a person between the age where she/he departs from compulsory education, and the age at which she/he finds her/his first employment and this paper will consider this definition to define youth (Naik \& Bobade, 2016).

Table 1: Labour Market Profile of Youths in 2016-17

\begin{tabular}{|l|c|c|c|}
\hline & Male & Female & All \\
\hline Youth (\% of total employed) & 27.4 & 35.0 & 29.5 \\
\hline Youth labour Force (\% of total LF) & 30.1 & 35.0 & 31.6 \\
\hline Youth Unemployed (\% of total unemployed) & 80.2 & 79.0 & 79.6 \\
\hline Youth Unemployed (\% of total youth) & 5.4 & 5.2 & 10.6 \\
\hline Youth Unemployed Rate (\%) & 8.2 & 15.0 & 10.6 \\
\hline Youth NEET (\% of total youth) & 8.1 & 49.4 & 29.8 \\
\hline
\end{tabular}

Source: Labour Force Survey Report 2016-17

Table 1 demonstrates that $29.5 \%$ of youths are employed among percentage of total employed. On the other hand, $10.6 \%$ are unemployed. In Bangladesh, unemployment rate is still high, overall unemployment rate is $10.6 \%$ (Naher, 2018) and 29.8\% of the youth are neither in education, employment nor in training. In addition to this, $49.4 \%$ of women fall in this category which is alarming for the overall labour market.

Bangladesh's economy has been doing well for the last several years but currently its job growth is the slowest in two decades. The sluggish job creation has raised questions about the high economic growth figures being recorded, with some economists terming the phenomenon "jobless growth" (Liton \& Molla, 2017).

\section{Methodology}

Data of the study are primarily from Bangladesh Bureau of Statistics (BBS), Labour Force Survey (LFS), Finance Division, Bangladesh Demographic and Health Survey (BDHS), United Nations Development Programme (UNDP) and Union Nations (UN) Population Division. In addition, major focus on secondary data collected from various published electronic and paper sources like international and national journals, government policies, reports and newspaper etc. The key searches include- demographic dividend, demographic dividend in Bangladesh, demographic disaster, youth employment etc. Microsoft Office Application Package is used in presenting graphical representation of data.

\section{Discussions}

\subsection{Demographic Dividend}

There is a concept of demographic dividend which is elaborated by Rao and Verghese (2009). In many countries, demographic shift is reached after the huge segment of adolescent and youth population joins the total population (Naik \& Bobade, 2016). The demographic dividend is the economic growth resulting from country's declining mortality and fertility and subsequent changes in the age structure of the population. Demographic dividend occurs when the majority of the population is working age and can contribute to the country's economy. Economists have identified four possible ways for the benefits of the demographic dividend. The first is the increased labour supply; however, the magnitude of this benefit will depend on the ability of the economy to absorb and productively employ the additional workers. The second is increased savings (resulting from reduced dependency ratio). The third is human capital. The fourth is the growth in domestic demand caused by the rise in 
per capita income and the reduced dependency ratio (Arefin, 2018).

\subsection{Demographic Dividend in Bangladesh}

The countries in South Asia would acquire a demographic dividend for a period of an average of 50 years. Among the countries, on an average, Bangladesh would acquire a highest dividend which is estimated at around 1 percent during the period of window of opportunity 1980-2020 (Sakina \& Alam, 2016). Demographic change in Bangladesh is opening up new economic opportunities. As in many countries, declining infant and child mortality helped to spark lower fertility, effectively resulting in a temporary baby boom. As this cohort moves into working ages, Bangladesh finds itself with a potentially higher share of workers as compared with dependents (Roy \& Kayesh, 2016). Bangladesh may endure aging problem by the year 2050, to some extent losing the demographic dividend of having more young population, suggests a UN report (Sakina \& Alam, 2016). Aging populations will bring about numerous challenges in the region, including rising costs for pensions and healthcare, higher dependency ratios, and changing family dynamics (Chand, 2018). Now, more than 65 percent of the populations are of working age, between 15 and 64. If appropriate policies are not formulated, the demographic dividend might, in fact, be a cost, leading to unemployment and an unbearable strain on education, health, and old age security (Matin, 2012). Yet, according to economists and population scientists, Bangladesh is unable to utilize the full potential of the demographic dividend, as it cannot create adequate number of jobs for the working-age population.

\subsection{Demographic Disaster}

Till date however, Bangladesh's capability to reap the rewards of its large demographic gain is uncertain. Despite improvements in maternal health and decreasing infant and child mortality, poor nutrition is a serious health problem in Bangladesh. Moreover, chronic diseases are on the rise in Bangladesh as the population becomes more urbanized. Health being one of the factors there are other challenges like employment rights, poor quality of education, lack of training and social restrictions and securities of women raise the question whether the increasing youth population will lead to be demographic dividend or demographic disaster (Naik \& Bobade, 2016).

\section{Challenges for youth employment}

\section{- $\quad$ Lack of Employment Opportunities}

The issue of youth unemployment in Bangladesh is very crucial for the overall development of the country. Due to the rapid growth of population, the country fails to create adequate opportunities for the youth in accordance with their educational qualifications and it significantly undermine the development potential of the economy and its transition to a higher growth trajectory (Mujeri, 2018). In addition, another difficulty that the most disadvantaged group in the society- the women face is not getting enough chances to enter into the job market for being woman despite of being capable enough to make a huge difference in the economic growth through their contribution. This group often faces discrimination and persistent gender inequalities, with some women experiencing multiple discrimination and exclusion because of factors such as ethnicity or caste (Paul et al., 2016). This lack of employment opportunities is functioning as a hinder for the youth labour force to be demographic dividend of this country.

\section{- Employment Rights}

In a context of ever-increasing costs of living and non-existent social protection, a young worker is destined not only to earn for him but also to provide for dependents. In intense anxiety, they accept any job with any conditions that are offered to them. Most of these jobs are without any rights. Sometimes they are made to work for longer hours, paid much less and can be fired from their job without any notice. As a consequence, Bangladesh is faced with growing numbers of working poor. The other challenge that young people are confronting is insecurity at the workplace. Regular and continuous forms of employment have been replaced with non-permanent job contracts that involve a specific project or activity for a defined period of time. In this scenario, employees not only lack employment-related benefits but also the capacity to plan their own life (Naik \& Bobade, 2016). 


\section{- Education and training}

Education in its general sense is a form of wisdom in which the ideas, knowledge, habits and skills of a group of people are transferred from one generation to the next through teaching, training, or research (Siddique, Shehzadi, Shaheen \& Manzoor, (2014). Bangladesh has made remarkable progress in increasing education access in the last 20 years (Al-Samarrai, 2009) but the majority of youngsters have either limited or no skills. About $29.8 \%$ of the youth of Bangladesh is neither in education, employment nor in training. In addition to this, the present education system does not prepare them for employment as it is far from meeting market demands. The avenues of good education and training are not many and extremely costly.

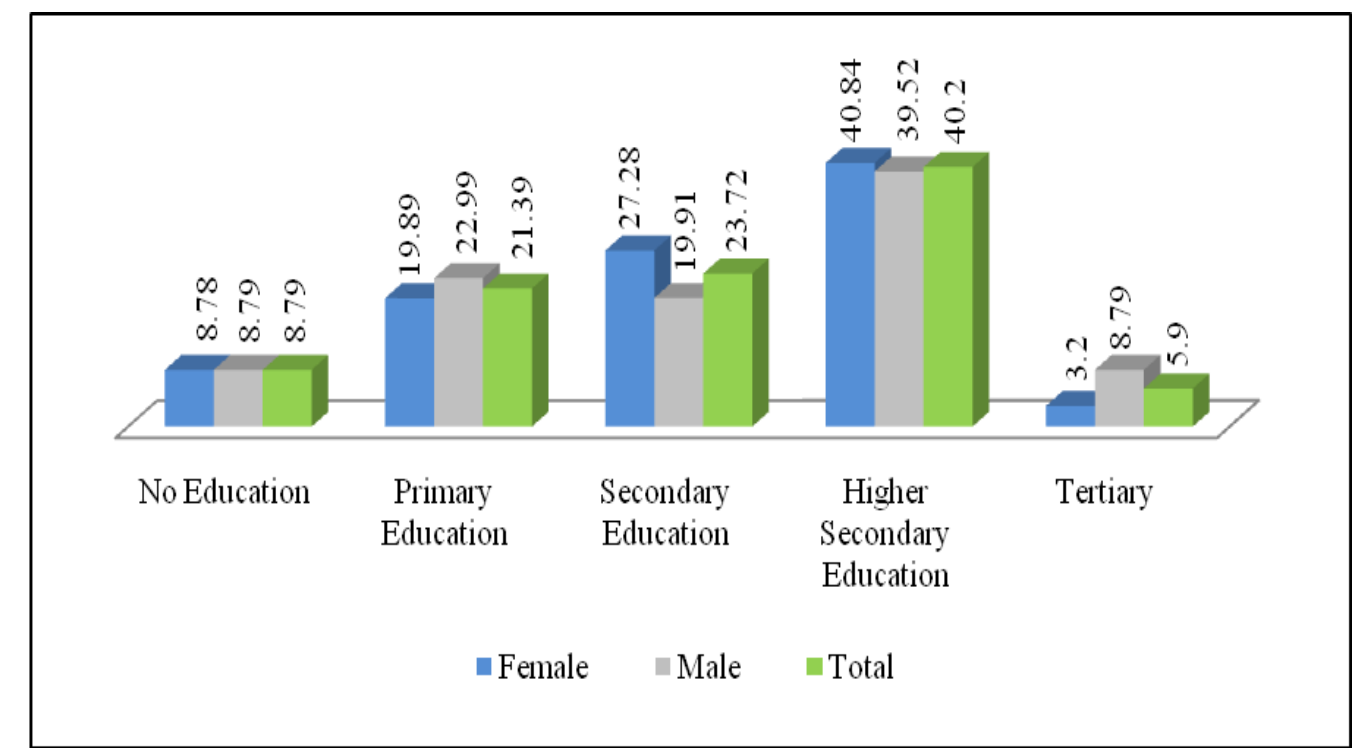

Figure 3. Education Profile of Youth Labour Force in 2016-17(\%)

Source: Labour Force Survey Report 2016-17

Figure 3 shows the education profile of youth labour force where we can notice both female and male education has drastically fallen in case of tertiary level. The overall percentage is not more than 40 up to higher secondary education which indicates that most of the youth in the labour force do not continue their studies after higher secondary hence; they are not eligible enough to meet the higher requirements to get a decent job.

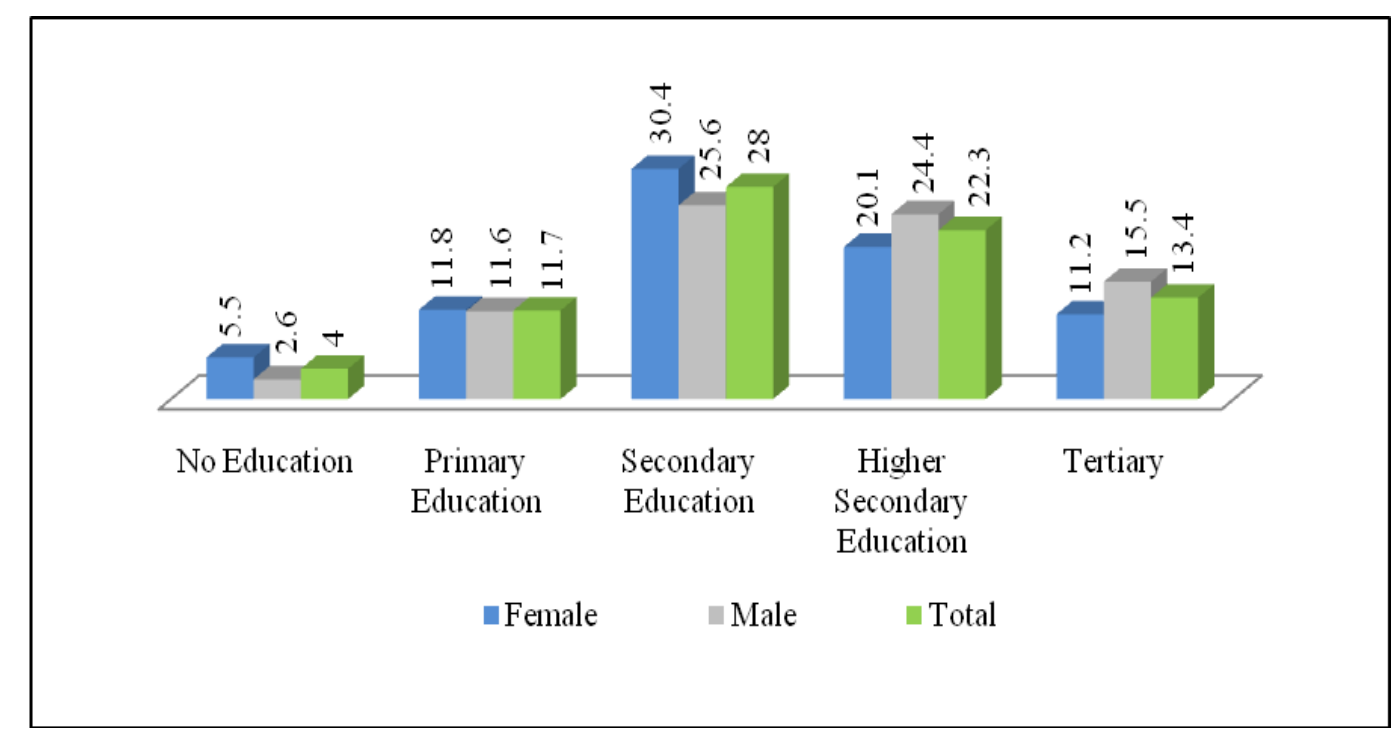

Figure 4. Educational Profile of Unemployed Youth in 2016-17(\%)

Source: Labour Force Survey Report 2016-17 
It is noticeable that at tertiary level total percentage of unemployed youth is $13.4 \%$ (Figure 4). It is clear from the data that in spite of being educated, youth of Bangladesh are still unemployed which is should be a big concern of the government.



Figure 5. Youth NEET (\% of total youth) in 2016-17

Source: Labour Force Survey Report 2016-17

Around $50 \%$ of the youth are not in education, employment or training in which the percentage is 29.8 for female and $8.1 \%$ for male (Figure 5). The education provided is often found of substandard quality and also very generalistic in nature; thereby creating a gap between what universities and colleges are supplying and what actually is needed by the industry (Rastogi, 2018). The lack of essential skills due to lack of involvement in various training among the youth and the resultant lack of employability is an outcome of the education system. From organization's point of view, they are trying to see how they can interact more with the universities and devise training programmes for students, so that the necessary skills can be imparted at an early stage, as opposed to industries running an expensive training programme at the customer's expense at the later stage.

Besides the above tribulations, young people in Bangladesh confront situation that is not rendering the desired support. The current scenario provides neither reasonably priced opportunities to acquire and/or upgrade skills nor sufficient knowledge on apt employment opportunities. In the absence of such support and any sort of social security, young people, in desperation, settle for exploitative employment conditions (World Bank, 2010).

\section{- Health Aspect}

The health system of Bangladesh relies heavily on the government or the public sector for financing and setting overall policies and service delivery mechanisms. Although the health system is faced with many intractable challenges, it seems to receive little priority in terms of national resource allocation (Islam \& Biswas, 2014). While fertility has declined, women have on average 2.3 children, and only about half use modern and effective contraceptive methods. Despite improvements in maternal health, Bangladesh still ranks in the bottom fourth of countries worldwide with approximately 240 deaths per 100,000 live births. Although infant and child mortality is decreasing, poor nutrition is a critical health problem in Bangladesh. About half of children age 6-59 months suffers from anemia; four-in-ten are stunted; and one in three is underweight. Bangladesh has one of the worst burdens of childhood malnutrition in the world.

Communicable diseases are a major cause of death and disability in Bangladesh. While the prevalence of tuberculosis (TB) has declined substantially, Bangladesh still ranks among the top ten countries in the world with the highest TB burden. The toll of non-communicable diseases — chronic diseases, cancer, diabetes, cardiovascular diseases, and chronic respiratory diseases — is increasing in Bangladesh as the population becomes more urbanized. In the first national survey to measure blood pressure and blood glucose, about one in three women and about one in five men age 35 and older has elevated blood pressure and roughly one in ten has elevated 
blood glucose, an indication of diabetes. Cancer is the sixth leading cause of death in Bangladesh, accounting for more than 150,000 deaths annually.

\section{- Women - Security and Social Restrictions}

The opening up of the Bangladesh economy has created increased employment opportunities for female workers, particularly in garments, educational institutions and banks as well. Their full engagement, however, remains constrained due to problems of personal security, biased attitudes of co-workers and social traditions and customs (Druskat \& Wheeler 2003). Occupational safety remains an issue with support being provided to implementing the National Occupational Safety Health (OSH) policy (ILO, 2019). Various studies have indicated child marriage (married by age of 18) is 59\%, adolescent birth per 1000 women aged $15-19$ is $83.5 \%$ and elderly care are the major causes of women workers withdrawing from the labour market. Additionally, a wife's labour is often viewed as a threat to male dominance and authority and can lead to various negative behaviours by the household head (Banks, 2013) and this mechanism is a major restriction for women participation in the labour market.

\section{Can We Seize the Demographic Dividend?}

At present there is 20.8 million youth in the labour force. Apart from university graduates, 20 lakh young people enter the job market every year, and they too do not fare any better -- a worrying development for a country which is blessed at the moment with a sizeable young population.

The rate of unemployment among persons with education of up to tertiary level rose to 13.4 percent in fiscal 2016-17 from nine percent a year earlier, according to the latest Labour Force Survey by the Bangladesh Bureau of Statistics (BBS). The unemployment rate has gone up at a time when higher numbers of graduates are coming out of universities, and the economy is registering steady growth.

Experts blame the absence of quality education and a skilled workforce as the main causes for not finding the right people for the job. Employers look for people with complex and adaptive thinking abilities who can cope with a multifaceted, volatile, and unpredictable job environment but our education system is producing jobless graduates (Habib \& Alamgir, 2019).

On the other side of the coin, women who are educated are more likely to work outside the home and, they are increasing the size of labour force and the potential for economic development. Enforcing policies that enable girls to go to school and equip them with skills to compete for higher-paying jobs is an important step toward gender equity that also fosters economic growth.

Suggestions are specified on taking up measures including large-scale investments in education and health sectors to cash in on the demographic dividend. According to the experts, the size of working-age population of Bangladesh would start to decline and the country may not get this dividend again in future. Though many countries have reaped the demographic dividend to develop their economies, things in Bangladesh are not on right track (Liton \& Molla, 2017).

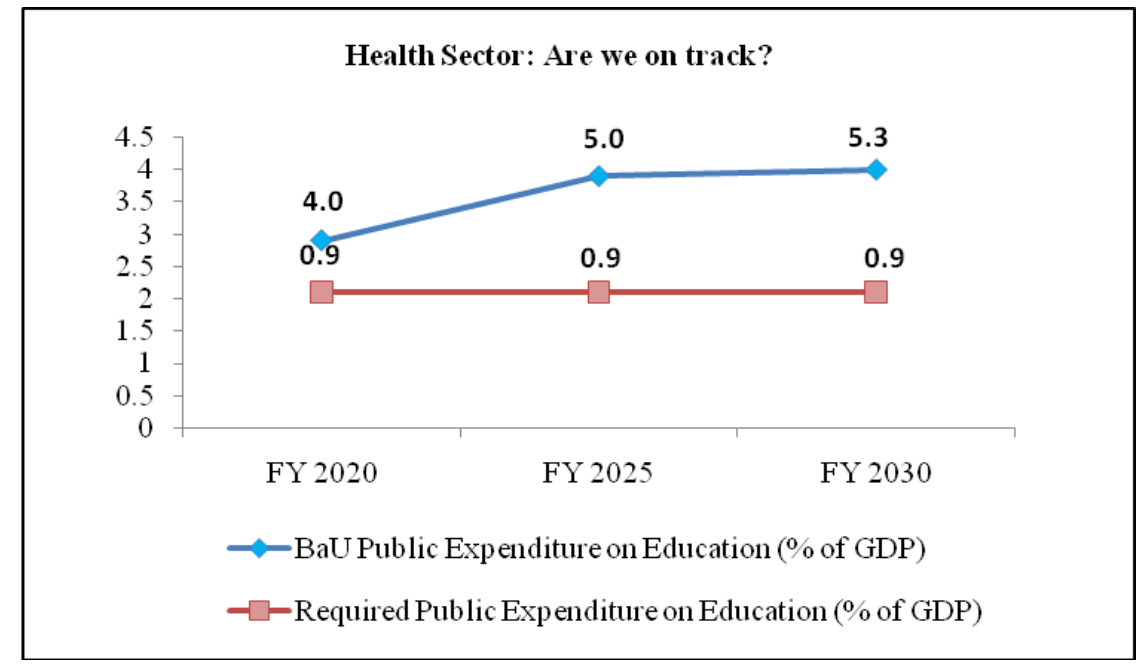

Figure 6. Scenario of Health Sector (FY 2020-30)

Source: Finance Division and Calculation by SANEM 


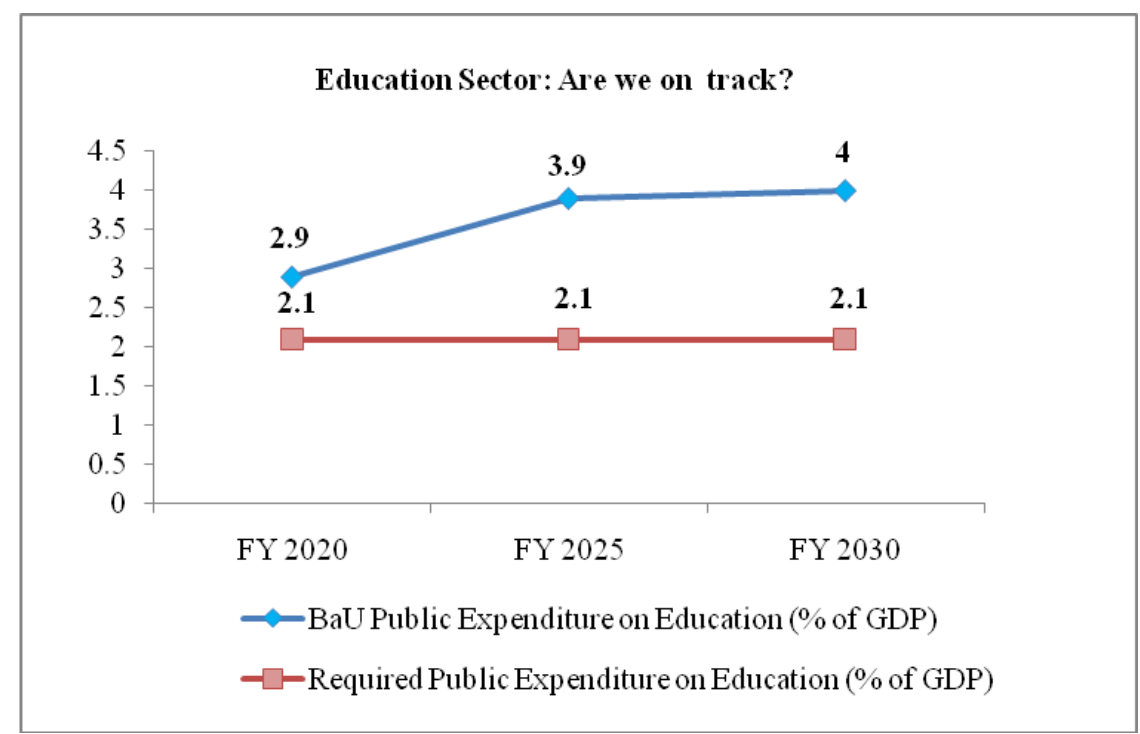

Figure 7. Scenario of Education Sector (FY 2020-30)

Source: Finance Division and Calculation by SANEM

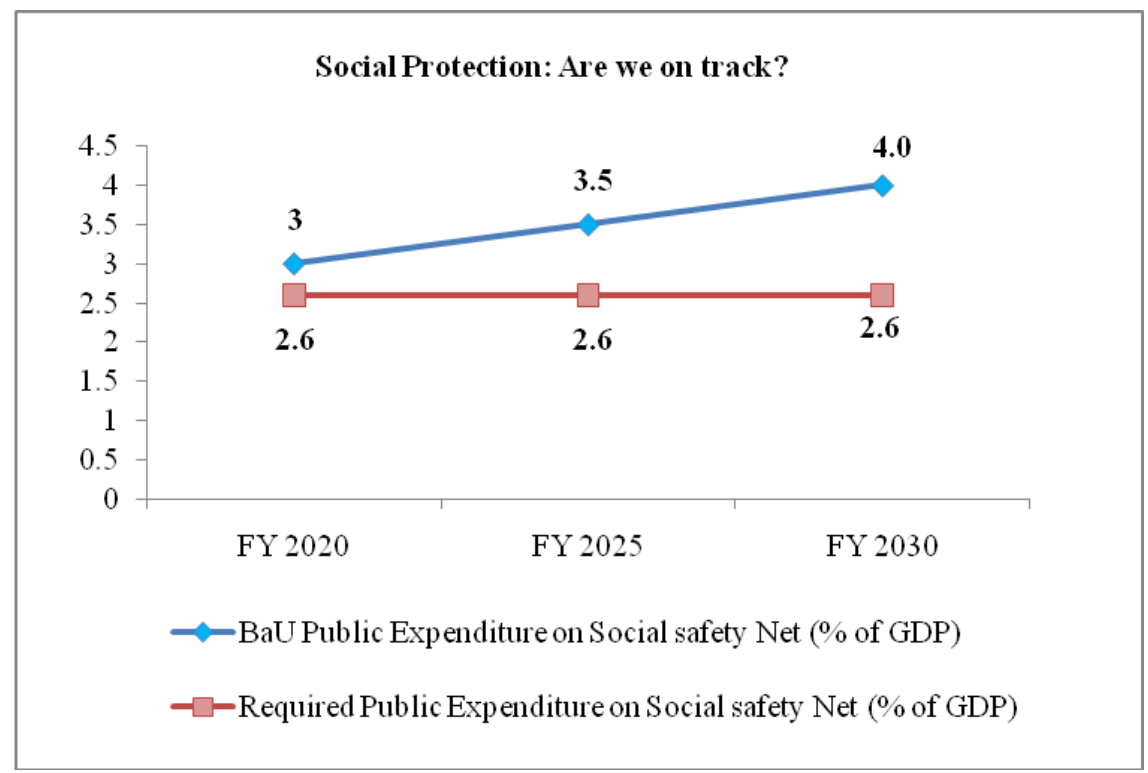

Figure 8. Scenario of Social Protection (FY 2020-30)

Source: Finance Division and Calculation by SANEM

In case of health sector, Bangladesh will need to increase its average total health spending to $5.3 \%$ of Gross Domestic Product (GDP) by 2030. In FY 2019-20 budget, the proposed allocation for health sector is $0.9 \%$ of GDP. Bangladesh needs to gradually increase its public expenditure on health by additional $4.4 \%$ of GDP (Figure 6). On the other hand, only $2.1 \%$ of GDP has been allocated for education in this budget. Therefore, public expenditure on education should be increased by $1.9 \%$ of GDP (Figure 7). Now considering the case of social protection, the average public social protection expenditure has been estimated to be around $4.0 \%$ of GDP (Figure 8). For FY 2019-20, the budget for social safety net is $2.6 \%$ of GDP excluding pension, it is only $1.8 \%$ of GDP that means allocation of another $1.4 \%$ of GDP is needed.

Sound macroeconomic management is the critical issue. An economy that has persistently high inflation is unlikely to be able to take the best possible advantage of a large segment of working-age people. However, demographic dividend depends on the policies the country chooses and on its political and economic relationships with rest of 
the world. The political leaders have to move fast to formulate education strategy and comprehensive financial plan to capture the once-in-lifetime opportunity.

Some key initiatives for youth development have been mentioned in budget 2019-20. Proposal of start-up capital to promote startup enterprises among youths, enlistment of Monthly Pay Order (MPO) schools, allocation for training of secondary teachers, allocation in research and development, increased allocation and coverage for mothers/pregnant women, allocation for interest free microcredit, raising small medium enterprises' yearly turnover threshold for taxation and proposal of a five year secondary education development programme are some of them in order to assist the development of youth, towards making them a productive workforce (South Asian Network on Economic Modeling (SANEM), 2019).

\section{Recommendations}

The findings of this research entail paying heed by policymakers, NGO workers, and affiliated authorities to address and deal with the following recommended issues very urgently. The study suggests some recommendations that are given below:

- The research suggests ensuring inclusive and impartial quality education in linkage to job markets needs and demands and endorsing lifelong learning opportunities for all. Under this suggestive measure, vocational education/training may serve the purpose shortly in a broader way.

- The study recommends promoting continuous, complete and sustainable economic growth through full and productive employment and decent work for all. It is the demand of time and statement of millions of unemployed youth who are eagerly sparing quality time to grab a job to contribute to the economy through their labor/skills.

- This study reflects that health is one of the major challenges faced by Bangladesh. So, budget allocation for health sector should be increased to ensure proper care for the youth working population, especially women.

- This research also suggests the need of easy access to the job market with a decent working environment is also required by youth boom to step up the economy. It is also important that the skills being learnt are relevant to the modern-day labour market.

- The study highly recommends to build resilient infrastructure, promote inclusive and sustainable industrialization, privatization, fosters innovation in linkage to agriculture, and establish action as well as academic research centers that will ultimately create more decent job opportunities, integrate local agriculture to industries, and reduce unemployment.

\section{Conclusion}

Bangladesh has experienced a sustained economic growth in last two decades even when there were more dependent age structure people in comparison to the working-age structure. In the mean-time, the country has faced demographic transition period successfully and dividend period gets started through the transition. Now the country has a huge number of working aged people in comparison to dependent aged structure and supposed to remain till 2040. Despite its demographic dividend and increased literacy levels, Bangladesh faces youth unemployment as a significant challenge for labour market policy. Unemployed youth comprise 79.6 percent of the total unemployed in Bangladesh. A significant number of well-educated youth in Bangladesh are either unemployed, underemployed, seeking employment or between jobs, or addressing insecure work arrangements. Bangladesh's main challenge concerning youth unemployment is the lack of any form of social security system, as well as proper and sufficient avenues for professional training. Financial aids have to be put into basic and further education, poverty eradication and health related initiatives. Furthermore, a quality education can offset the social factors that hinder women's labour market participation. Besides education, health is key to nation-building. The success mantra of transforming the demographic dividend into an economic growth lies not just in having more people, but generating large numbers of better skilled, healthier and more dynamic people. Overall, the challenge is in terms of both job creation and the preparation of young people for the labour market to guarantee that Bangladesh's demographic dividend does not become demographic disaster. 


\section{References}

Abdulah, K. (2017). Demographic Dividend in Bangladesh: Quest for Initiatives. Society \& Change. 11(3), 45-46.

Al- Samarrai, S. (2009). The impact of governance on education inequality: Evidence from Bangladesh. Public Administration and Development. 29 (3), 167-179. DOI.org/10.1002/pad.529.

Ahmed, S. D., \& Alam, O. (2016). Demographic Dividend in Bangladesh: Opportunities and Challenges. ASIAN JOURNAL OF MULTIDISCIPLINARY STUDIES. 4(4), 108-113.

Arefin S. (2018), Demographic Dividend and Bangladesh [online] Available: http://m.theindependentbd.com/printversion/details/136152 (July 19, 2019)

Banks, N. (2013). Female employment in Dhaka, Bangladesh: participation, perceptions and pressures. Environment and Urbanization. 25(1), 95-109. DOI: 10.1177/0956247813477357

Chand, M. (2018). Aging in South Asia: challenges and opportunities. South Asian Journal of Business Studies. 7 (2), 189-206. DOI.org/10.1108/SAJBS-09-2017-0103.

Desk, S. (2015), Adolescents and young people of Bangladesh [online] Available: https://www.thedailystar.net/adolescents-and-young-people-of-bangladesh-54257 (July 31, 2019)

Druskat, V. U. \& Wheeler, J. V. (2003). Managing from the Boundary: The Effective Leadership of Self managing Work Teams. The Academy of Management Journal. 46 (4), 35-57.

Habib, W. B.\& Alamgir, M. (2019, Jun). A little for the jobless. Retrieved July 19, 2019, from https://www.thedailystar.net/bangladesh-national-budget-2019-20/little-the-jobless-1756870

Haider. A. A. (2019), 'Demographic dividend' could turn into a 'demographic disaster' [online] Available: https://www.thedailystar.net/lifestyle/perspective/news/demographic-dividend-could-turn-demographic-disaster-170927 2 (July 19, 2019)

International Labour Organization (ILO). (2013). Global Employment Trends 2013. Geneva: International Labour Office.

International Labour Organization (ILO). (2018). World Employment and Social Outlook: Trends 2018. Geneva: International Labour Office.

International Labour Organization (ILO). (2019). Youth Employment. Geneva: International Labour Office.

Islam, A. \& Biswas, T. (2014). Health System in Bangladesh: Challenges and Opportunities. American Journal of Health Research. 2(6), 366-374. DOI: 10.11648/j.ajhr.20140206.18.

Liton, S. \& Molla, A. M. (2017), Demographic Dividend: Big opportunity passing by [online] Available:https://www.thedailystar.net/frontpage/unemployment-problem-in-bangladesh-big-opportunity-passing-econo mic-growth-1431280 (July 17, 2019)

Matin, K. A. (2012). The Demographic Dividend in Bangladesh: An Illustrative Study. In 18th Biennial Conference of the Bangladesh Economic Association, 12-14 July 2012 (pp. 2-20). Dhaka: Bangladesh Economic Association.

Mujeri, M. K. (2018), 'Jobless growth' in Bangladesh [online] Available: https://www.thedailystar.net/opinion/economics/jobless-growth-bangladesh-1607386 (July 19, 2019)

Naher, S. (2018). Perceptions of Employability among Employers in Bangladesh. IOSR Journal of Economics and Finance (IOSR-JEF). 9 (1), 23-29. DOI: 10.9790/5933-0901032329.

Naik, K., \& Bobade, A. (2016). Youth in India: Demographic Dividend or Demographic Disaster. In $9^{\text {th }}$ Euromed Conference on Innovation, Entrepreneurship and Digital Ecosystems, September 14-16, 2016 (pp. 1362-1373). Warsaw, Poland: EuroMed Press.

Paul, G. K., Sarkar, D. C. \& Naznin, S. (2016). Present Situation of Women Empowerment in Bangladesh. International Journal of Mathematics and Statistics Invention (IJMSI). 4(8), 31-38.

Poutiainen, T. (2019), Skills learning changes lives and must be lifelong [Online] Available: https://www.thedailystar.net/opinion/education/news/skills-learning-changes-lives-and-must-be-lifelong-1771351(July 19, 2019)

Rastogi, H. (2018). Youth population: An asset - only when supported by education and employability. International Journal of Academic Research and Development. 3(2), 1394-1398.

Roy, M., \& Kayesh, S. (2016). Reaping Demographic Dividend in Bangladesh Challenges and Prospects. Global Journal of HUMAN-SOCIAL SCIENCE: E Economics. 16(2), 11-20.

Siddique, H. M. A., Shehzadi, I., Shaheen, A., \& Manzoor, M. R. (2014). The impact of Governance and Institutions on Education and poverty Alleviation: A Panel Study of SAARC Economics. Sci.Int. (Lahore). 28(2), 1431-1435.

World Bank. (2010). World Development Report 2010: Development and Climate Change. Washington, DC: World Bank Group. 